\title{
KONCEPCJA REWITALIZACJI FARY W GUBINIE. PRÓBA WYKORZYSTANIA ENERGII SŁONECZNEJ W PROCESIE ADAPTACJI ZABYTKOWEGO KOŚCIOŁA NA CENTRUM KULTURY I KOMUNIKACJI
}

\begin{abstract}
Artykuł prezentuje próbę wykorzystania energii odnawialnej (słonecznej) przy adaptacji Fary Gubińskiej na funkcje Centrum Kultury i Dialogu. Wieloletni proces ratowania i rewitalizacji późnogotyckiego kościoła doprowadził do przeprowadzenia konkursu urbanistyczno - architektonicznego mającego umożliwić wykorzystanie znajdującej się dziś w ruinie budowli fary przez mieszkańców miast Gubina i Guben. Gotycki kościół stanowi ważny element krajobrazu pogranicza polsko - niemieckiego. Wieloletnie badania dostarczyły wiedzy o licznych fazach powstawania i przebudowy budynku kościoła. Problem wprowadzania proekologicznych rozwiązań związanych z produkcją energii odnawialnej przy projektowaniu w obrębie zabytkowych budynków i zespołów jest tematem bardzo aktualnym. Polityka promowania rozwiązań proekologicznych coraz częściej wpływa na projektowanie konserwatorskie. Poszukiwania rozwiązań celem połączenia nowoczesnej technologii i zabytkowych wartości dają bardzo różnorodne rozwiązania. W przypadku koncepcji adaptacji średniowiecznej fary zabytkowe i architektoniczne wartości budowli wymusiły poszukiwanie nie ingerującego w bryłę budynku sposobu umiejscowienia instalacji paneli fotowoltaicznych (pod przeźroczystym pokryciem dachowym). Prezentowany eksperyment pokazał możliwość niestandardowego podejścia do próby połączenia nowoczesnych technologii z historyczną bryłą obiektu. Pomimo prób minimalizowania wpływu nowych instalacji na obiekt zabytkowy najlepszym rozwiązaniem pozostaje właściwe kształtowanie formy i poszukiwanie takiego programu funkcjonalnego dla obiektu, który wykorzysta jego atuty, oraz lokowanie zaawansowanych technologicznie funkcji poza obiektami zabytkowymi. Efekt wprowadzania do zabytkowych obiektów nowoczesnych, ,proekologicznych” instalacji jest zwykle kontrowersyjny. Pytanie czy jest to właściwe rozwiązanie czy tylko chwilowa moda.
\end{abstract}

Słowa kluczowe: projektowanie, ochrona zabytków, energia solarna, energooszczędność

\footnotetext{
${ }^{1}$ Anna Małachowicz, Katedra Konserwacji Zabytków, Wydział Budownictwa i Inżynierii Środowiska Politechniki Rzeszowskiej, 35-959 Rzeszów, Al. Powstańców Warszawy 12, tel. 178651041 (51-637 Wrocław, ul. Bernardyńska 5/8), a_malach@prz.edu.pl; kkz@prz.edu.pl
} 
Kościół farny w Gubinie, wpisany do rejestru zabytków województwa lubuskiego pod nr 281, jest jedną z ostatnich, nie odbudowanych po wojnie, monumentalnych ruin. Największy i najbardziej rozpoznawalny budynek w mieście stanowi jego wizytówkę. Ceglany kościół góruje nad otaczającą go zabudową i jest widoczny z dużej odległości.

Znaczenia procesowi rewitalizacji fary dodaje fakt jego położenia przy granicy polsko - niemieckiej oraz historia jego użytkowania wpierw jako świątyni katolickiej, a następnie protestanckiej. Oprócz władz miasta Gubina w proces odbudowy fary zaangażowane są fundacja „Fara Gubińska (utworzona w 2005 r.), niemieckie „Stowarzyszenie Wspierające Odbudowę Kościoła Farnego w Gubinie" oraz powstały w 2011 r. polsko - niemiecki Warsztat Konserwatora Fary Gubińskiej. Wśród prac zmierzających do przywrócenia świetności i zachowania zabytku należy wymienić przekrycie dachem budynku dawnej szkoły (1979-80 r.), rekonstrukcję hełmu, , prace zabezpieczająco - porządkowo - remontowe w latach 2007-08 oraz budowę klatki schodowej - trasy turystycznej prowadzącej na punkt widokowy na wieży kościelnej.

Powyższe argumenty stanowią, z jednej strony zachętę do przywrócenia pełnej świetności bryle kościoła poprzez odtworzenie jej charakterystycznego wysokiego dachu, z drugiej strony ożywiają dyskusję czy i jak powinno się odbudowywać taki zabytek, zwłaszcza, że po odbudowie nie będzie on pełnił funkcji sakralnej. Temat przebudowy (odbudowy) kościoła stawił temat międzynarodowych warsztatów architektonicznych, które dały bardzo zróżnicowane wyniki oraz podsumowanie w formie koncepcji Centrum Kultury i Komunikacji.

Centrum ma służyć funkcjom kulturalnym, turystycznym, komunalnym, naukowym i ekumenicznym.

Rozstrzygnięcie o formie odbudowy i adaptacji fary dla potrzeb nowej funkcji miał przynieść realizacyjny konkurs na opracowanie koncepcji urbanistyczno - architektonicznej Fary Gubińskiej jako Centrum Kultury i Komunikacji w ramach projektu: Renowacja Wieży Kościoła Farnego w Euromieście Gubin - Guben - warsztaty transgraniczne rozwoju kultury, sztuki i nauki. ${ }^{2}$ na koncepcję odbudowy fary. W artykule prezentuję rozwiązanie zaproponowane przez zespół Autorskiej Pracowni arch. Macieja Małachowicza ${ }^{3}$.

W regulaminie konkursu znalazły się następujące wytyczne: „pkt. 2.3.2. Zgodnie z wytycznymi Lubuskiego Wojewódzkiego Konserwatora Zabytków

\footnotetext{
${ }^{2}$ Konkurs był prowadzony w oparciu o art. 11 ust.8 ustawy Prawo zamówień publicznych z dnia 29 stycznia 2004r.. na podstawie zwycięskiej pracy autorstwa pracowni Heinle, Wischer und Partner Sp. z o.o. powinna zostać opracowana w 2014 r. dokumentacja (projekt budowlany i wykonawczy) która będzie podstawą odbudowy kościoła.

${ }^{3}$ Prezentowana w artykule praca konkursowa została wykonana przez zespół w składzie: dr inż. arch. Maciej Małachowicz; mgr inż. konstruktor Florian Nadolski, mgr inż. arch. Rafał Karnicki, mgr inż. arch. Anna Małachowicz współpraca inż. arch. Andżelika Jonik; inż. arch. Ada Fijał; inż. arch. Marek Obajtek
} 
forma odtworzenia Fary Gubińskiej winna uwzględniać ideę konserwatorską odbudowy obiektu, zakładającą odtworzenie budowli w jej historycznej bryle, stanowiącej dominantę architektoniczną i symboliczną w zespole urbanistycznym: odtworzenie formy historycznej bryły kościoła w tym:

- odbudowę wysokiego spadzistego dachu nad korpusem,

- zamknięcie otworów okiennych,

- zabezpieczenie, utrwalenie i wyeksponowanie autentycznej, historycznej substancji zabytkowej fary."

Wśród założeń projektowych znalazł się także postulat przeanalizowania możliwości wprowadzenia w obiekcie odnawialnych źródeł energii, w tym energii słonecznej, oraz innych rozwiązań mających zminimalizować oddziaływanie obiektu na środowisko oraz koszty jego eksploatacji.

$\mathrm{W}$ celu pełnego rozpoznania i wykorzystania wartości zabytkowej budowli proces odbudowy poprzedziły prace badawcze i inwentaryzacyjne. Kościół został przebadany archeologicznie w latach 1970 - 71 przez PPKZ oddział w Poznaniu ( w południowo zachodnim narożu kościoła) i architektonicznie kolejne badania były prowadzone $\mathrm{w} 2008 \mathrm{r}^{4}$.

Badania ujawniły sześć faz powstawania kościoła w Gubinie oraz funkcjonowanie w tym miejscu dwóch budowli poprzedzających dzisiejszy, późnogotycki kościół. Pierwszy kościół parafialny lokowanego w 1235 r. miasta Gubina (wcześniejsza osada handlowa istniała tu od XI w.) prawdopodobnie pod wezwaniem św. Marii Magdaleny [3] ${ }^{5}$ miał formę trójnawowej bazyliki z prostokątnym prezbiterium zakończonym absydą. Absydami zakończone były też od wschodu nawy boczne. Od zachodu bryłę świątyni zamykał westwerk z dwoma wieżami.

Pod koniec XIII wieku powiększono prezbiterium nadając mu prostopadłościenny, wydłużony obrys. Z pierwszego kościoła zachowały się ceglane, murowane w wątku dwuwozówkowym, ściany korpusu i prezbiterium (pod posadzką dzisiejszego wnętrza kościoła, posadowione ok. $2 \mathrm{~m}$ poniżej poziomu posadzki oraz, w niepełnej wysokości, wieże, wtopione w dzisiejszy masyw zachodni).

Po pożarze wzniesiono w tym miejscu nowy trójnawowy kościół - gotycką halę. Zdecydowanie powiększono prezbiterium, które było nieznacznie tylko węższe od korpusu nawowego. Wyniki badań nie pozwalają na jednoznaczne odtworzenie architektury tej części.

\footnotetext{
${ }^{4}$ Wyniki pierwszych badań w: C.Lasota, J.Rozpędowski, Rozwój przestrzenny kościoła parafialnego w Gubinie, Prace Naukowe Instytutu Architektury Sztuki i Techniki Nr 13/ 1980. W kwietniu i maju 2008 roku przeprowadzone zostały badania georadarowe we wnętrzu kościoła prowadzone przez zespół: Nawrocki W. , Antosiewicz W, Pieczonka J. Wyniki "Badania georadarowe Kościoła Farnego w Gubinie" w:"Fara -badania" Gubin 2008 w tym samym roku prace antropologiczno - archeologiczne prowadził J.Lewczuk oraz badania architektoniczne prowadzone przez zespół dr M.Małachowicza

${ }^{5}$ Works J.G.'Inwent.dipl.Lusitiae Inter. Nr 278- document dla klasztoru w Dobrymługu wystawiony w kościele Marii Magdaleny w Gubinie
} 
Korpus nawowy zachował wymiary zbliżone do pierwotnego. Przy budowie filarów oddzielających nawy wykorzystano posadowienie romańskich ścian arkadowych. Ośmioboczne w rzucie filary stanowiły oparcie dla gurtów dźwigających sklepienia naw.

Przebudowano wnętrze wież. Odcięto ich przyziemie od przestrzeni kościoła, co mogło być związane ze znacznym podniesieniem poziomu posadzki.

Dzisiejszy późnogotycki kościół farny składa się z budynku d. szkoły będącej pozostałością rozbudowy prezbiterium w I-szej połowy XV wieku, późnogotyckiego prezbiterium, ukończonego przed. 1508 r. oraz wybudowanych w latach 1508-1559 trójnawowego korpusu z kaplicami i wieży.

Kościół, mający mury z cegły pełnej grubości od $1,1 \mathrm{~m}$ do ok. $3 \mathrm{~m}$, cechuje się dużą bezwładnością cieplną, a temperatura w jego wnętrzu powinna być dodatnia niezależnie od pory roku. Ściany kościoła posiadają dobrą izolacyjność cieplną, jednak przeszklenie otworów stolarką z szybą zespoloną jest możliwe tylko w mniejszych otworach budynku d. szkoły/ zakrystii czy wieży. W ścianach naw bocznych znajdują się wysokie $(9,4 \div 9,6 \mathrm{~m}$, szer. ok. $2 \mathrm{~m})$ ostrołuczne otwory okien w nawach bocznych. Należy w nich przywrócić, zdemontowane w trakcie praz zabezpieczających, kamienne maswerk. Ze względu na swoją budowę (ozdobne obramienie z kształtek ceglanych oraz kamieniarkę) okna mogą być zamknięte jedynie pojedynczą taflą szklaną.

Aby zachować walory architektoniczne i zabytkowe Gubińskiej Fary zrezygnowano z termomodernizacji budynku, rozumianej jako docieplenie przegród. Ze względu na bardzo duże zapotrzebowanie na energię celem ogrzania wnętrz kościoła uznano, że najlepszym rozwiązaniem będzie czasowe ogrzewanie kościoła np. przy okazji organizacji koncertów, a w pozostałym czasie pozostawienie tej przestrzeni nieogrzewanej.

Elementem łączącym minimalizowanie zużycia energii i postulat konserwatorski pokazania odkrytych w trakcie badań archeologicznych fundamentów romańskiej fary było odsłonięcie wnętrza historycznej zakrystii (zdecydowano się na wykorzystanie wnętrza pierwotnego prezbiterium zakończonego półkolistą absydą) i naw bocznych późnoromańskiej bazyliki, przekrycie ich stropem i umieszczenie w tej części ekspozycji stałej oraz mniejszej sali wielofunkcyjnej mogącej pomieścić 80 osób.

Wykorzystanie romańskiej arkady - funkcjonującego w XIII przejścia pomiędzy nawą a pomieszczeniami w przyziemiu wież - pozwoliło wprowadzić wejście do pomieszczeń podziemnych od strony placu rynkowego (obecnie pl. Jana Pawła II), co pozwala na niezależne funkcjonowanie pomieszczeń ekspozycyjnych oraz sali wielofunkcyjnej.

W projekcie przyjęto, że w budynku dawnej szkoły zlokalizowana zostanie kawiarnia (bar cateringowy) biblioteka i pomieszczenia administracji oraz w piwnicy pomieszczenia techniczne i toalety. Pomieszczenia te będą ogrzewana przez cały okres grzewczy z węzła c.o. umiejscowionego w piwnicy dawnej szkoły, a pozostałe przestrzenie w zależności od stopnia ich wykorzystania. 


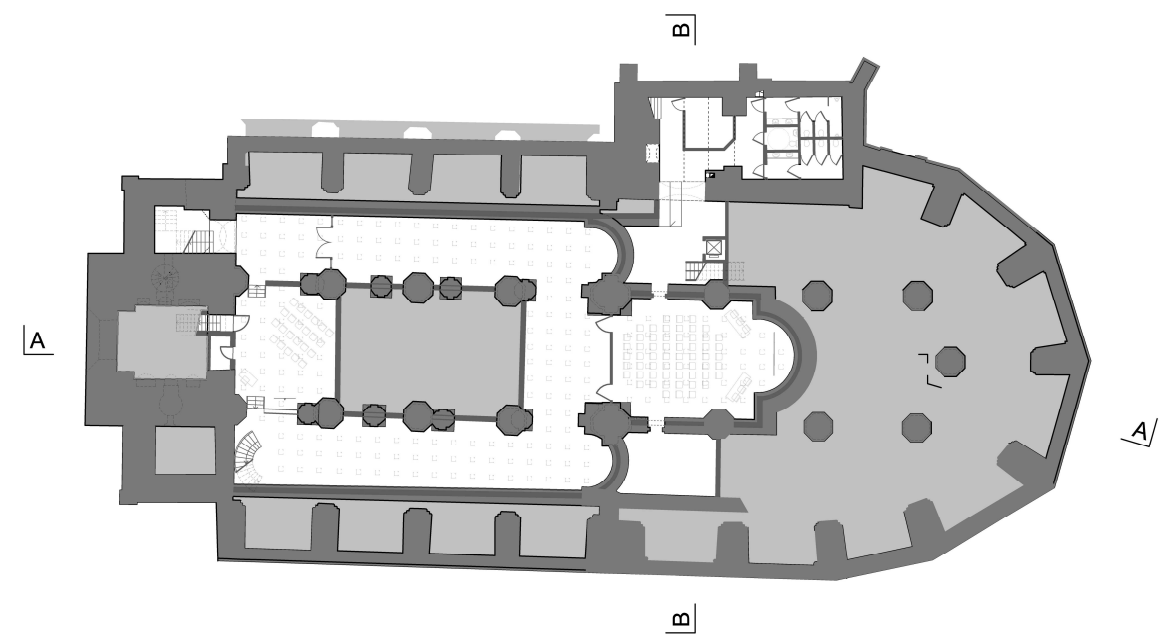

Rys. 1. Rzut kondygnacji podziemnej. Adaptacja wnętrza romańskiego kościoła

Fig. 1. Underground floor plan. Adaptation of the interior of the Romanesque church

Mniej intensywnie wykorzystywane pomieszczenia (studio nagrań) zostanie ulokowane w wieży kościelnej, w pomieszczeniu nad kruchtą. Pomieszczenia te, dostępne dla ograniczonej liczby osób, miały być ogrzewane elektrycznie.

Pomieszczenia ekspozycyjne - Archiwum Dziedzictwa, które w zamyśle autorów programu Centrum Kultury i Komunikacji ma stanowić depozyt detali architektonicznych np. rzeźb, kształtek ceramicznych itp. znalezionych w trakcie prac konserwatorskich i badawczych w celu ich ponownego wkomponowanie w wystrój obiektu lub stworzenia z nich ekspozycji dydaktycznej, zostały ulokowane w kaplicach przylegających do naw bocznych korpusu fary. Za względów użytkowych zostały zamknięte szklanymi, nowoczesnymi ściankami.

Dzięki takiemu ukształtowaniu funkcji udało się zachować historyczne wnętrze fary oraz uzyskać bardziej zrozumiałą niż np. rysunek w posadzce ekspozycję wnętrze późnoromańskiej budowli oraz ograniczono zapotrzebowanie na energię.

Takie rozwiązanie pozwala dodatkowo na różnorodne, zależne od potrzeb i inwencji użytkowników aranżowanie i dzielenie przestrzeni fary w związku z organizowanymi wystawami, koncertami, warsztatami etc. nie zabiera przy tym możliwości zobaczenia unikalnej architektury gotyckiego kościoła w formie zbliżonej do pierwotnej.

Problem ułożenia na zabytkowym budynku, instalacji słonecznych był dużym wyzwaniem.

Wysoki dach, którego formę znamy dzięki zachowanemu odciskowi na ścianie zachodniej, będzie widoczny ze wszystkich stron i znacznej odległości. 
W koncepcji zdecydowano się na odtworzenie tradycyjnego, ceramicznego pokrycia dachowego. Pomysł ustawienia na dachu ,typowych" konstrukcji mocujących i paneli wydawał się nie do zaakceptowania.

Problemem jest też pogodzenie istniejącej bryły budynku z wymogami technologicznymi (spadek dachu w połaci południowej wynosi ok. $58^{\circ}$ zaś optymalne odchylenie paneli powinno wynieść $20-40^{\circ}$ ).

$\mathrm{W}$ pracach konkursowych oraz poprzedzających konkurs koncepcjach proponowane było różnorodne podejście do tej kwestii, w większości ograniczone do uporządkowania i zmniejszenia ustawionych na połaci dachowej paneli fotowoltaicznych.

Inne rozwiązanie zaproponował zespół Autorskiej Pracowni arch. Macieja Małachowicza

Aby zachować wygląd i charakter zewnętrznych elewacji kościoła zaproponowano przekrycie części połaci dachowej przezroczystą, szklaną dachówką i ustawienie paneli fotowoltaicznych na poddaszu.

„Przeszklenia” zostały zakomponowane w formie ozdobnej szachownicy, stosowanej na dachach budynków średniowiecznych.

Panele pod pokryciem dachowym mogą być ustawione pod optymalnym kątem, jednak ich efektywność zmniejszy się wskutek odbicia części energii słonecznej przez szklana dachówkę.

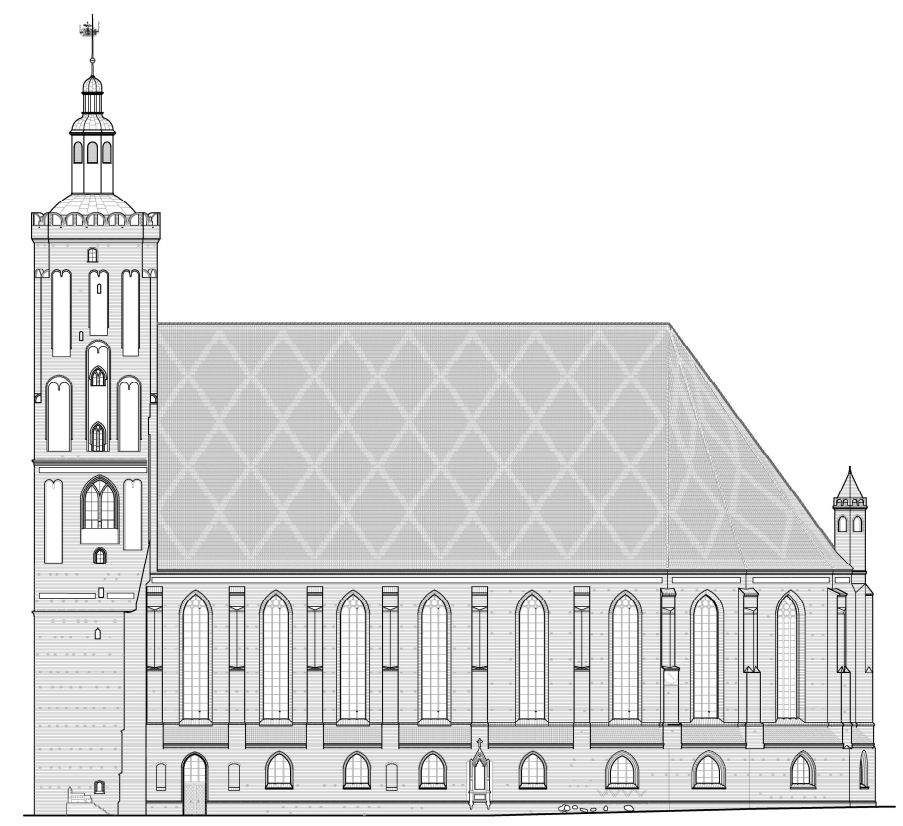

Rys. 2. Elewacja południowa kościoła farnego w Gubinie

Fig. 2. South elevation of the parish church in Gubin 
Dla potrzeb koncepcji przyjęto, że czasowe zacienianie części powierzchni min. przez konstrukcje więźby zmniejszy efektywność urządzeń o ok. 40\%.

Zmniejszenie ilości produkowanej energii elektrycznej rekompensuje częściowo łatwy dostęp do całej instalacji, bezpieczne jej serwisowanie (bez konieczności wychodzenia na dach) oraz mniejsza podatność na uszkodzenia i możliwość zamontowania tańszych urządzeń.

Atutem jest też możliwość wykonania instalacji w dowolnym momencie, bez ustawiania rusztowań i wprowadzania zmian w pokryciu dachowym.

Ustawienia na powierzchni poddasza paneli fotowoltaicznych nie uniemożliwia adaptacji tej przestrzeni na funkcje ekspozycji, magazynowe itp. Pomieszczenia poddasza mogły by być adaptowane do potrzeb nowej funkcji i funkcjonować niezależnie od podziemnej trasy ekspozycyjnej oraz biur i biblioteki w budynku szkoły, choć wejście na poddasze wymaga przejścia przez kościól. Wg wstępnych szacunków dla potrzeb koncepcji konkursowej pod dachem fary można ustawić panele produkujących ok. 10-40 kWh rocznie.

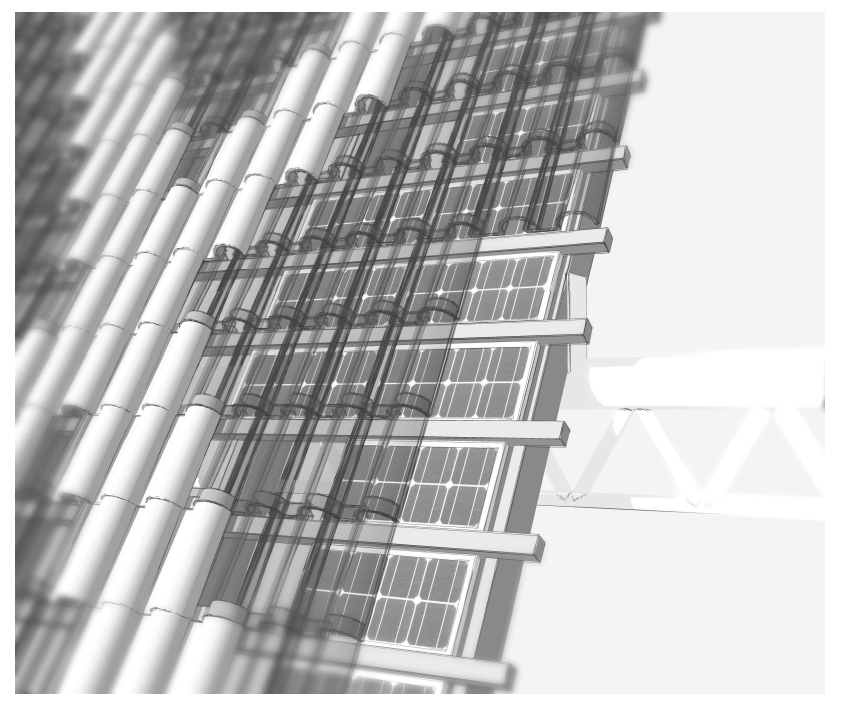

Rys. 3. Schemat umieszczenia paneli fotowoltaicznych

Fig. 3. Schematic placement of photovoltaic panels

Ukrycie nowoczesnej, kontrastującej z wystrojem architektonicznym elewacji kościoła instalacji paneli fotowoltaicznych pod szklanym dachem pozwala pogodzić postulat konserwatorski zachowania bryły i formy.

Decyzja o wykonaniu przeziernego pokrycia z dachówki, a nie np. tafli szklanej, była podyktowana potrzebą zachowania faktury dachu.

$\mathrm{Z}$ punktu widzenia efektywności i kosztu takiego rozwiązania możemy postawić pytanie czy jest sens, przy obecnej technologii, stosowania instalacji np. paneli fotowoltaicznych przy rewaloryzacji obiektów zabytkowych. Czy wobec 
niewykorzystania np. dachów i elewacji sąsiadujących $\mathrm{z}$ farą zabudowań mieszkalnych $\mathrm{z}$ wielkiej płyty umieszczanie paneli na zabytkowym kościele nie jest zbytnim podążaniem za chwilową modą?

Najefektywniejszą metodą ograniczania zapotrzebowania na energię w budynkach zabytkowych pozostaje właściwe lokowanie funkcji, w tym przenoszenie pomieszczeń mających duże wymagania instalacyjne do nowych budynków i poszukiwanie, przy adaptacji zabytku, programu użytkowego zbliżonego do pierwotnego np. wykorzystanie kościoła jako sali audytoryjnej czy koncertowej.

\title{
Literatura
}

[1] G. Domański: "Początki Gubina i jego fary" w: Ruiny zabytków sakralnych ochrona i adaptacja do nowych funkcji - materiały z międzynarodowej konferencji naukowej Gubin 6-8 .11.2008 r.

[2] C. Lasota, J. Rozpędowski: Rozwój przestrzenny kościoła parafialnego w Gubinie, Prace Naukowe Instytutu Architektury Sztuki i Techniki Nr 13/ 1980

[3] M. Małachowicz, Badania architektoniczne Fary Gubińskie w 2008 roku, Wrocław - Gubin 2008, maszynopis. Praca konkursowa z lipca 2013 r. wykonana przez zespół Autorskiej Pracowni arch. Macieja Małachowicza - regulamin konkursu wraz z załącznikami.

\section{CONCEPTION OF REVITALIZATION OF PARISH CHURCH IN GUBIN. AN ATEMPT TO USE SOLAR ENERGY IN ADAPTATION OF GOTHIC CHURCH FOR THE FUNCTIONS OF CENTRE OF CULTURE AND DIALOGUE}

\begin{abstract}
S u m m a r y
The article presents an attempt to use renewable (solar) energy to the adaptation of the parish church in Gubin for the functions of Center for Culture and Dialogue. The long process of rescuing and revitalization of the late Gothic church led to an urban - architectural contest designed to allow the use of the ruined parish church by urban residents of Guben and Gubin. The Gothic church is an important element in the landscape of the Polish - German borderland. The issue of introducing ecofriendly solutions related to the production of renewable energy in designs of historic buildings and sites is very up-to-date. The policy of promoting ecological solutions increasingly affects restorative designs. The search for solutions to combine modern technology and historic values provides varied outcome. In the case of the concept of adaptation of the medieval parish church, historic and architectural values of the building necessitated the search for the way of positioning photovoltaic panels (under the transparent roof covering) not interfering with the body of the building. An attempt to minimize the impact of new technologies on the historical object is always a kind of compromise. The best solution remains to create a form and searching for proper functional program. This should use the advantages of certain object. A fine way out might be also to localize necessary advanced technologies outside the monument. The result of implementation of modern and so-called ecological installations is usually controversial. The question is, if this is a well solution or only temporary trend.
\end{abstract}

Keywords: design, historic preservation, solar energy, energy efficiency

Przestano do redakcji: $24.03 .2015 \mathrm{r}$.

Przyjęto do druku: 22.06.2015 r.

DOI:10.7862/rb.2015.58 